\title{
Three Typical Hydrological-Hydrochemical Situations Near the Danube River Mouth Based on the Marine Hydrophysical Institute Research Expeditions in 1997-2013
}

\author{
S. I. Kondratev \\ Marine Hydrophysical Institute of RAS, Sevastopol, Russian Federation \\ skondratt@mail.ru
}

\begin{abstract}
Purpose. The paper is aimed at studying the present state of water ecology of the Black Sea northwestern shelf (NWS). Since the early 60-ies of the last century, ecology in this region deteriorated seriously due to intensive anthropogenic load that resulted in eutrophication of waters and regular fish mortality in the warm period of a year.

Methods and Results. In 1997-2013 Marine Hydrophysical Institute realized 7 hydrological and hydrochemical expeditions near the Danube mouth. The dissolved oxygen and nutrients (nitrate, nitrite, phosphate and silicic acid) contents were analyzed in the water samples collected at the bottom (0.5-1 $\mathrm{m}$ above the bottom) and surface $(0-1 \mathrm{~m})$ horizons.

Conclusions. Revealed are three hydrological-hydrochemical situations typical of the region: distribution of the transformed Danube flow far to the east, pressing of the Danube flow to the west coast of the Black Sea and alongshore upwelling. Silica and nitrate are rapidly and almost completely extracted from the seawater (the latter one - even in early winter) during photosynthesis in the surface waters on the NWS. The processes of particulate organic matter mineralization in the bottom waters of the NWS are assumed to be an additional source of silicic acid and nitrates. As for silicic acid, the process takes place during a warm season, and for nitrates - even in early winter. The alongshore upwelling in summer can lead to oxygen deficiency in the coastal waters and that, in its turn, can result in fish mortality on the shelf. The waters of the northwestern shelf open part which, in autumn 2010, pressed the Danube transformed freshwater flow to the Black Sea west coast, contained very small concentrations of biogenic elements (low content of silicic acid should be particularly noted). The study confirms the fact that the hazardous process of change in the phytoplankton species composition still continues, thus, altering the whole food chain in the Black Sea.
\end{abstract}

Keywords: northwestern shelf (NWS) of the Black Sea, estuarine area near the Danube mouth, dissolved oxygen, nutrients, along-coastal upwelling, field studies.

Acknowledgments: the investigation is carried out within the framework of the state task on theme No. 0827-2018-0003 "Fundamental studies of the oceanologic processes conditioning the marine environment state and evolution under the impact of natural and anthropogenic factors based on the methods of observations and modeling" and theme No. 0827-2019-0004 "Complex interdisciplinary investigations of the oceanologic processes conditioning functioning and evolution of the Black and Azov seas' coastal zones".

For citation: Kondratev, S.I., 2019. Three Typical Hydrological-Hydrochemical Situations near the Danube River Mouth Based on the Marine Hydrophysical Institute Research Expeditions in 1997-2013. Physical Oceanography, [e-journal] 26(4), pp. 326-340. doi:10.22449/1573-160X2019-4-326-340

DOI: $10.22449 / 0233-7584-2019-4-326-340$

(C) 2019, S. I.Kondratev

(C) 2019, Physical Oceanography

\section{Introduction}

In the 60ies of the last century, serious deterioration of the ecological situation on the Black Sea northwestern shelf (NWS) took place due to water anthropogenic eutrophication that, in its turn, resulted in regular fish mortality in summer. Four large rivers (the Danube, the Dnieper, the Dniester and the Southern Bug), the total 
water basin of which exceeds the NWS area by 23 times [1], bring industrial, agricultural and household wastewater to the Black Sea from a dozen European countries. The data of satellite images [2] testify to the fact that sometimes the transformed freshwater runoff of these rivers spreads throughout the whole NWS, reaching Cape Tarkhankut and sometimes Cape Chersonesos. But more often it propagates to the south along the western coast (Fig. 1). In any of these options, the highest anthropogenic load falls on the coastal water area which extends from the Danube mouth to the Dnieper-Bug estuary, and in some cases receives the flows of all four rivers (in the event that the Danube flow moves to the south, the same eutrophicated waters come from the north).

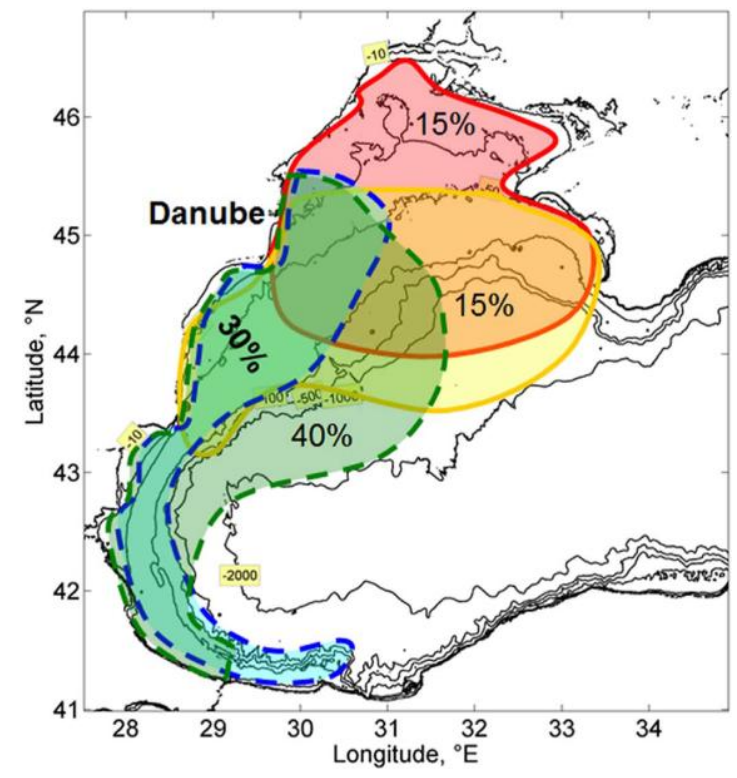

F i g. 1. Propagation of the Danube transformed freshwater flow in summer based on chlorophyll distribution in the surface waters [2]

The freshwater runoff in this region provides phytoplankton with the inorganic forms of nitrogen, phosphorus, and silicon in course of a whole year that stimulates phytoplankton to bloom at the NWS not only in spring and autumn, but also in winter $[3,4]$. However, the most environmentally dangerous situation on the NWS is observed in the warm season. At the beginning of the spring-summer period (April May [5, 6]) due to the water heating, a density stratification (including both temperature and salinity) occurs on the NWS. It provides spread of the transformed river runoff over the surface that results in rise of the nutrients high concentrations in the warm brackish surface waters. This leads to intensive development of phytoplankton (which gradually consumes nutrients) and to high content of the dissolved oxygen (formed during photosynthesis) in the surface waters.

In the bottom waters, the reverse process takes place, i.e. oxygen is consumed for oxidizing the precipitated particulate organic matter (POM) and for returning of the nutrients' dissolved forms to the aqueous phase. In the presence of a thick pycnocline limiting vertical exchange, penetration of oxygen from the surface to 
the bottom waters is possible only as a result of wind mixing. Under unfavorable meteorological conditions (prolonged calm weather) at the end of a summer period (August - September), the oxygen content in the NWS bottom can decrease up to hypoxia, at which water saturation with oxygen becomes less than $30 \%$.

Perhaps, just the final stage of hypoxia development, i.e. appearance of hydrogen sulfide after complete disappearance of oxygen and subsequent result fish mortality, induced the increased attention to NWS in the second half of the XX century. This phenomenon has been regularly and comprehensively discussed in the scientific papers [7-21] containing permanent conclusions on unfavorable ecological situation at NWS. In recent years, a number of publications testify to some improvement of ecology on the shelf [22-25] and to partial restoration of the Zernov phyllophore field [26, 27]. However, the fish mortality in the Dnieper-Bug estuary [28] which was observed over $15 \mathrm{~km}$ along its coast in August, 2018 [28], showed that eutrophication of the northwestern basin still continues. Though the Dnieper-Bug estuary is only a small shallow part of the shelf, its anthropogenic load will inevitably affect the whole shelf.

In 1997-2013 Marine Hydrophysical Institute (MHI) spent 7 expeditions near the Danube mouth, some of the results were represented in [20, 21]. Summarizing of the results made it possible to reveal three, in our opinion, "characteristic" hydrological-hydrochemical situations, in which:

- the transformed freshwaters of the Danube River spread freely to the east or northeast;

- the transformed freshwaters of the Danube River were pressed to the western coast of the Black Sea and then moved to the south penetrating to the east not farther than 5 miles;

- as a result of the along-coastal upwelling in the summer period, decrease of the oxygen content was observed in the surface waters of the estuary coastal areas.

In the recently proposed classification of the variants of the transformed Danube runoff distribution on NWS in summer (based on satellite observations [2]), the first two situations were called the "eastern" and the "western" types of distribution. Two more variants were also considered there, but, in both these cases, the areas were located outside the MHI polygon. The present paper is devoted to a detailed examination of spatial distribution of the hydrological and hydrochemical characteristics in three identified "typical" situations.

\section{Data and methods}

The state of the Danube estuary waters was investigated by the MHI scientists in September and October, 1997 at the R/V "Trepang", in December, 1998 at the R/V "Diorit", in November, 2001 at the R/V "Vikhr", in August, 2009 at the R/V "Sapfir" and in October, 2010 and September, 2013 at the R/V "Professor Vodyanitsky". The hydrochemical observations were performed at the stations network shown in Fig. 2. More detailed schemes of the stations for individual cruises are given in the figures demonstrating spatial distribution of nutrients. 


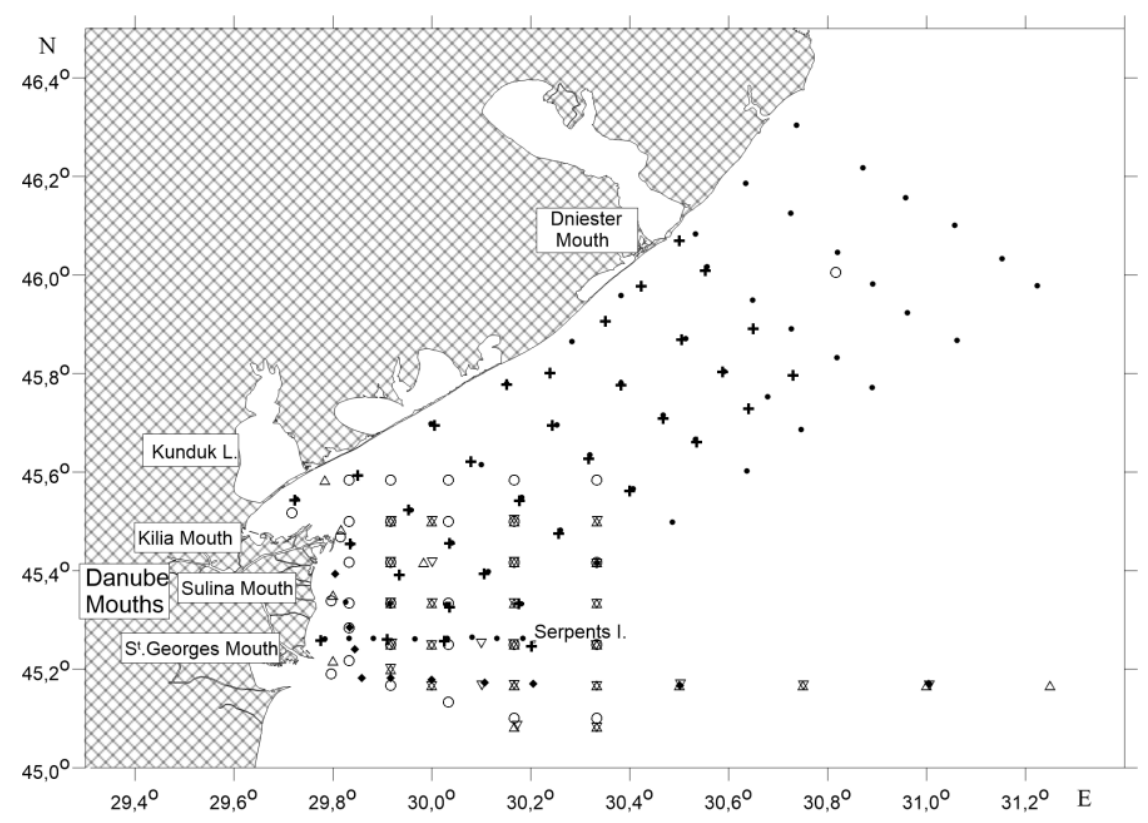

F i g. 2. Scheme of the stations performed by MHI NAS of Ukraine in the Danube near-mouth region: $\Delta$ - September, 1997, R/V "Trepang"; $\nabla$ - October, 1997, R/V “Trepang”; o - December, 1998, R/V "Diorit"; • - November, 2001, R/V "Vikhr"; + - August, 2009, R/V "Sapfir"; • October, 2010, September, 2013, R/V "Professor Vodyanitsky"

Instrumental hydrological observations and samplings were done by the probing complexes Seabird-Electronics in the expeditions on the R/V "Professor Vodyanitsky", and by the shelf measuring complex SHIK-3 - in the other cruises. At the bottom $(0.5-1 \mathrm{~m}$ from the bottom) and surface $(0-1 \mathrm{~m})$ horizons, the water samples were taken by a cassette of plastic bathometers. Concentrations of nutrients (nitrates, nitrites, phosphates and silicic acid) were analytically determined, as a rule, in the stationary laboratory of the Marine Biogeochemistry Department of MHI. For this purpose the samples were put in the $250 \mathrm{ml}$ plastic containers and frozen immediately at $-18{ }^{\circ} \mathrm{C}[20,21]$.

The chemical-analytical determinations were carried out according to the methods recommended for hydrochemical studies of the ocean waters [29]. To calibrate the instruments for the physical-chemical methods of measurements and for controlling accuracy of the analysis results, the certified standard samples produced by STC "Physical-Chemical Institute, NAS of Ukraine" were used.

\section{Spread of the transformed freshwater flow far to the east or to the northeast}

December, 1998. Such a distribution was stated in two seasons: in early winter (beginning of December), 1998 and in summer (August), 2009. Let us consider in details the features of spatial distribution of the hydrochemical elements in these cases. 

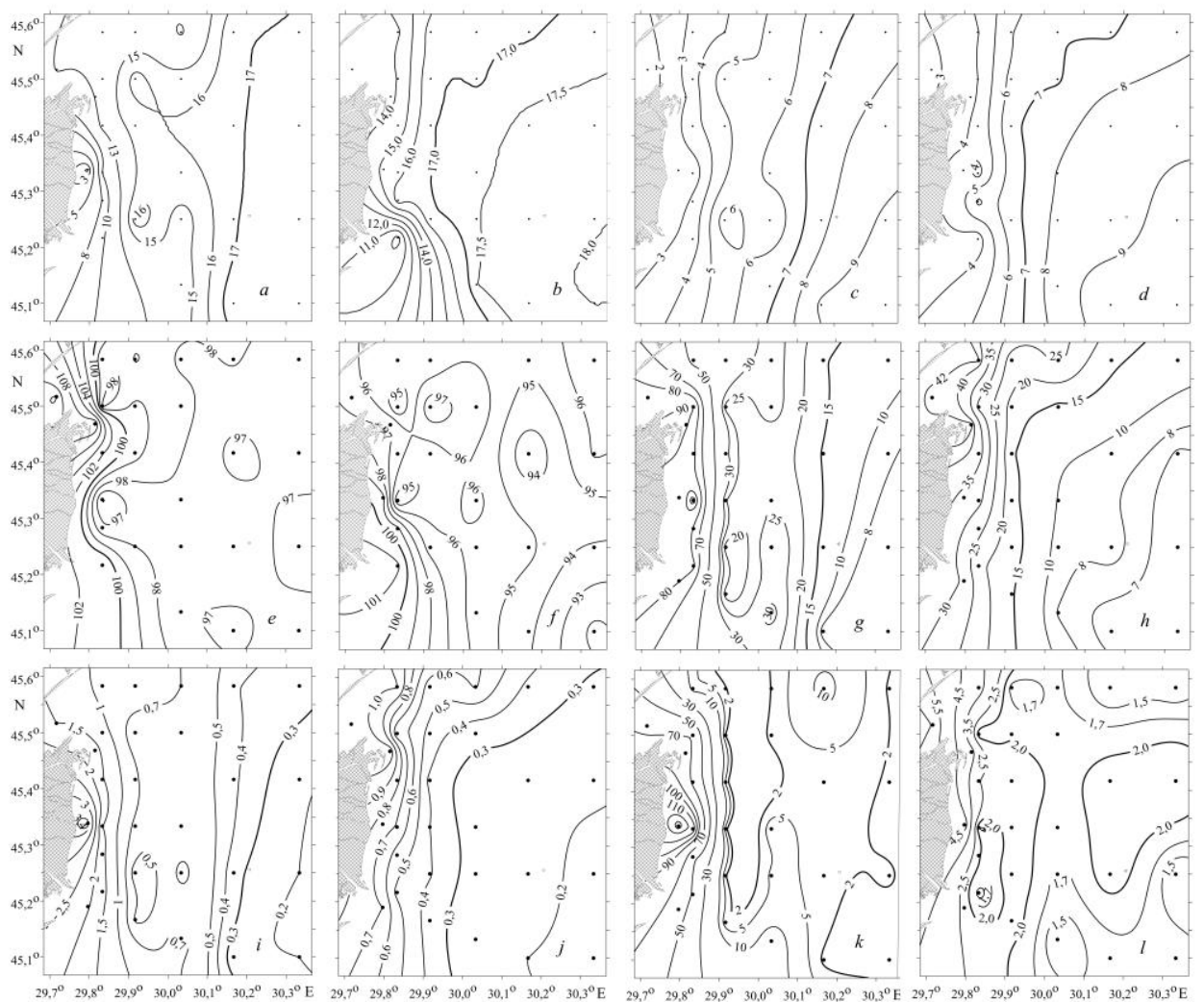

F i g. 3. Distribution of salinity, $\%(a, b)$, temperature, ${ }^{\circ} \mathrm{C}(c, d)$, oxygen saturation, $\%(e, f)$, content $(\mu \mathrm{M})$ of silicic acid $(g, h)$, phosphate $(i, j)$ and nitrate $(k, l)$ in the surface $(a, c, e, g, i, k)$ and bottom $(b, d, f, h, j, l)$ waters in December, 1998

In early spring, 1998, the following distribution of hydrological and hydrochemical characteristics over the polygon was observed (Fig. 3). Salinity of the surface waters gradually grew with distance from the Danube mouth from 3\%o opposite the Sulina branch to $17 \%$ (the values taken as a boundary where the fresh and sea waters mix in the Black Sea [30]) nearby $30.2^{\circ} \mathrm{E}$ (Fig. 3, a). Salinity of the bottom waters near the mouth was significantly higher: about $15 \%$ near the Sulina branch and $11 \%$ near the St.George one. However, the bottom 17\% isohaline was located not so far from the surface one - at about $30^{\circ} \mathrm{E}$.

In contrast to salinity, the surface and bottom water temperatures did not differ significantly even near the Danube mouth; and after it reached $6^{\circ} \mathrm{C}$ on the surface at a distance of approximately 10 miles from the mouth, the vertical temperature gradient became almost zero. When salinity became $11-12 \%$, the densities $\left(\sigma_{t}\right.$ scale $)$ of the surface and bottom waters became the same, but did not exceed $\sigma_{t}=13.7 \mathrm{~kg} / \mathrm{m}^{3}$ throughout the whole polygon under study. At the same time, the water density at the shallow-water (11 m depth) station (located to the north) opposite the Dniester mouth $\left(30.82^{\circ} \mathrm{N}, 46^{\circ} \mathrm{E}\right)$ reached $\sigma_{t}=14.0 \mathrm{~kg} / \mathrm{m}^{3}$, i.e. in this region (and, hence, to the north) the cold coastal waters began to penetrate under the water of lower density in the open part of the shelf. 
Such a mixture of river and sea waters at the beginning of winter and at not very intensive photosynthesis should have been accompanied by gradual decrease of the nutrients' content in the surface waters with distance from the Danube mouth. Similar situation [15] was indeed observed for the silicic acid and phosphates distribution (Fig. 3, $g-j$ ). In the surface and bottom waters near the Danube mouth, high concentrations of both elements quickly decreased with distance from the coast that resulted in a monotonic vertical distribution near $30.1^{\circ} \mathrm{E}$.

However, as for the oxidized forms of nitrogen, such a "conservative" distribution (i.e., practically linear dependence of the hydrochemical element content on the salinity value) in the surface waters was not observed. The nitrates concentrations in the surface and bottom waters decreased sharply near the $13 \%$ o isohaline and further to the east remained at about $2 \mu \mathrm{M}$ throughout the whole water column (Fig. 3, $k, l$ ). On the contrary, the nitrites content over the whole polygon, regardless of the salinity value, was $0.4-0.5 \mu \mathrm{M}$, and only in the surface waters near the Sulina branch increased to $0.8-0.9 \mu \mathrm{M}$.

The noted difference in the nutrients behavior while mixing of the river and sea waters in December, 1998 was confirmed by the altering contents of four forms of nutrients with increase of salinity (Fig. 4). As for silicic acid and phosphates, the concentration and salinity relation was almost linear after salinity exceeded $12 \%$. For the oxidized forms of nitrogen, the situation was completely different: the content of nitrates decreased almost 10 times when salinity reached the value exceeding $12 \%$, whereas the nitrites content almost did not depend on salinity. Significant spread of the concentrations of nitrates, silicic acid and phosphates in the freshened (4-10\%) waters is associated, possibly, with samplings in different regions of the polygon under study. In the expeditions in summer, 1995, in winter and spring, 1997 [15], the samples were taken at the stations located compactly near the individual branches to the west from $30^{\circ} \mathrm{E}$. In December, 1998 the size of the MHI polygon was much larger.

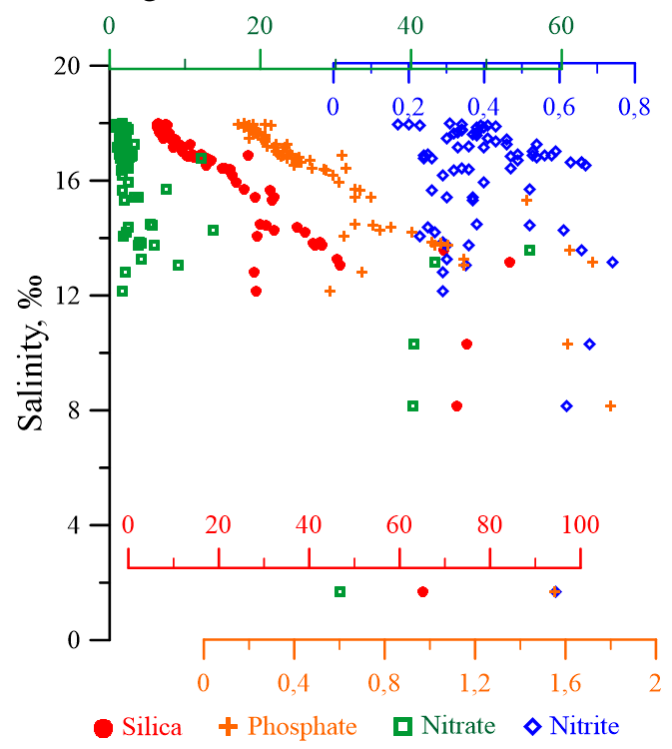

F i g. 4. Distribution of silicic acid, phosphate, nitrate and nitrite concentrations $(\mu \mathrm{M})$ relative to salinity in December, 1998

PHYSICAL OCEANOGRAPHY VOL. 26 ISS. 4 (2019) 
Removal of nitrates from the river runoff together with simultaneous conservative behavior of silicic acid permits to assume that in early winter, 1998 the photosynthesis processes did not stop completely, but silicon-containing phytoplankton (diatoms) did not participate in them. Thus, growth of diatoms requires not only certain minimum concentration of silicic acid in water, estimated as $2 \mu \mathrm{M}$ [15], but also certain temperature; the other types of phytoplankton are not so exacting to the growth conditions.

The assumptions on the ongoing process of photosynthesis (winter blooming of phytoplankton near the Danube mouth was observed not once by chlorophyll $a$ distribution in the surface waters [4]) are also confirmed by the data on water saturation with oxygen. In the open part of the shelf, water saturation with oxygen constituted 97-98\%; at the same time, near the coast it was higher, attaining 100$102 \%$ opposite the Sulina branch and 108-110\% opposite the Chilia branch (Fig. 3,e). 100-102\%-saturation can be explained at least by decrease of oxygen solubility with salinity increase in the process of the river and sea water mixing; whereas high 108-110\%-saturation with oxygen testifies to the fact that, in spite of low $\left(2-3{ }^{\circ} \mathrm{C}\right)$ water temperature, photosynthesis in the Zhebriyans'ka Bay protected from the north-western winds, did not stop completely. The processes of POM mineralization in the bottom waters also continued: at almost the same temperature and salinity, the surface water saturation with oxygen to the east from $30^{\circ} \mathrm{E}$ was not lower than $97 \%$, whereas in the bottom water - it did not exceed 94 95\% (Fig. 3, f).

August, 2009. The maximum effect of the river runoff upon distribution of the hydrological and hydrochemical characteristics in summer was observed in the Danube mouth coast in August, 2009. In winter, 1998 the freshwater runoff significantly affected only the vertical salinity gradients on the closest to the mouth water area located to the west from $30^{\circ} \mathrm{E}$; whereas in summer, 2009, temperature and salinity of the surface and bottom waters differed throughout the whole polygon under study (Fig. 5, $a-d$ ).

Salinity of the freshened surface waters did not exceed $15 \%$, on the bottom horizon it was not less than $17.3 \%$. Temperature on the surface was about 24$25^{\circ} \mathrm{C}$, at the bottom - only about $10-12{ }^{\circ} \mathrm{C}$. The feature of the hydrological structure was a lens of the freshened warm waters (temperature at the bottom exceeded $20{ }^{\circ} \mathrm{C}$ ), its diameter was about 15 miles, thickness - about $20 \mathrm{~m}$, and the center was at $45.5^{\circ} \mathrm{N}, 30.5^{\circ} \mathrm{E}$. The contents of some hydrochemical components in the bottom waters of this lens were noticeably different from the background ones.

Intensive photosynthesis in the surface waters provided their at least $105 \%$ saturation with oxygen over the whole polygon, and near the Chilia branch it exceeded $135 \%$ (Fig. 5,e). On the contrary, oxygen consumption for POM mineralization in the bottom waters resulted in extensive hypoxia with saturation lower than $30 \%$ almost over the whole polygon (except for the lens of the freshened water), and in the coastal areas saturation dropped up to 5\% (Fig. 5, $f$ ). If we take into consideration the fact that the bottom water samples were taken at the $1 \mathrm{~m}$ horizon from the bottom, it is quite possible to assume that hydrogen sulfide appeared in the water at the very bottom. 

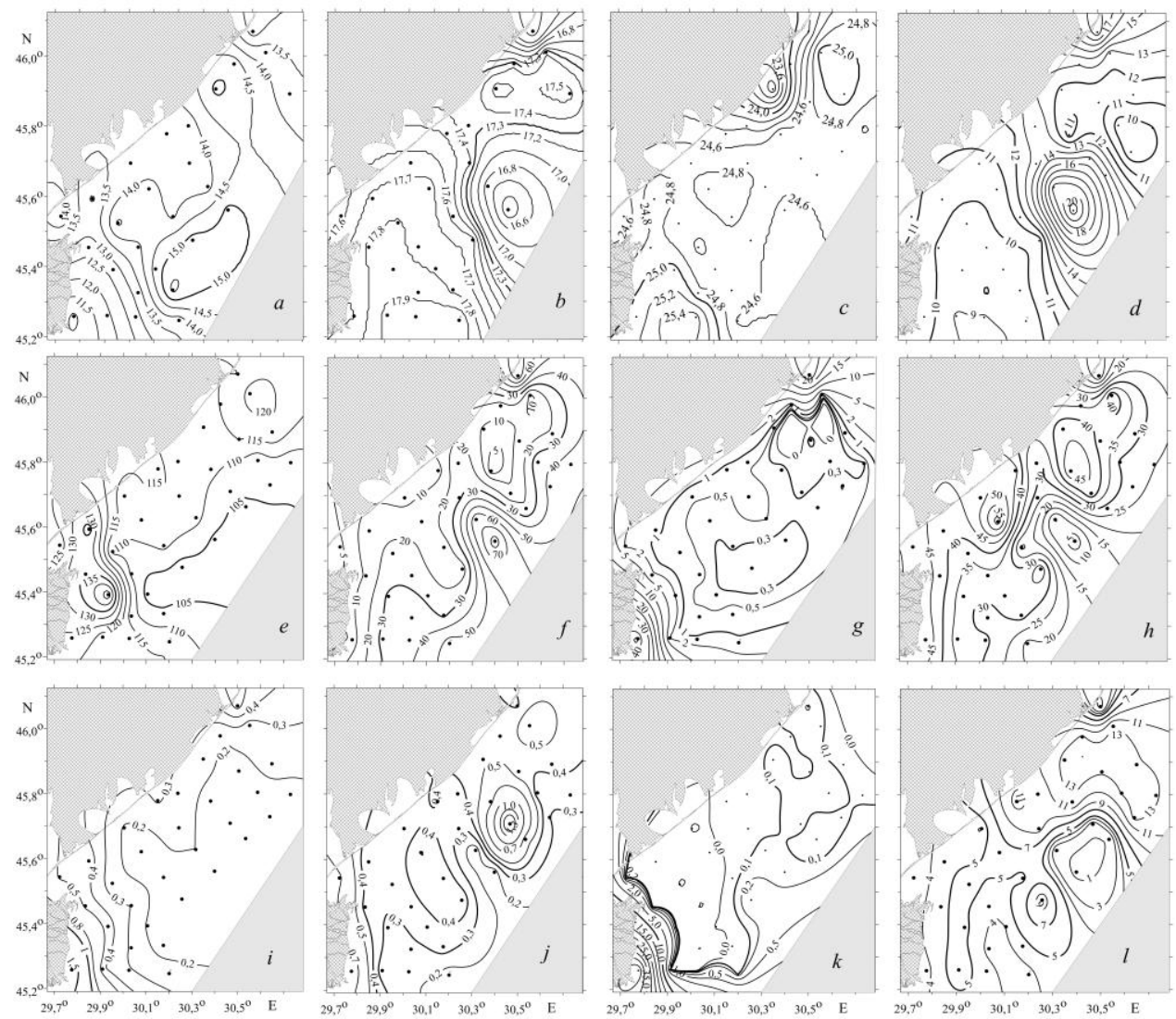

F i g. 5. Distribution of salinity, \%o $(a, b)$, temperature, ${ }^{\circ} \mathrm{C}(c, d)$, oxygen saturation, $\%(e, f)$, content $(\mu \mathrm{M})$ of silicic acid $(g, h)$, phosphate $(i, j)$ and nitrate $(k, l)$ in the surface $(a, c, e, g, i, k)$ and bottom $(b, d, f, h, j, l)$ waters in August, 2009

At active photosynthesis, silicic acid and nitrates were quickly consumed in the warm surface waters, their content at a distance of 10 miles from the coast decreased by about 100 times as compared to the Danube runoff (Fig. 5, $g, k$ ). The analogous decrease (but not so significant) - only by about 10 times - was observed also for phosphates (Fig. 5, i). Summing up the silicic acid and nitrates distributions in the surface waters makes it reasonable to note that, although the transformed freshwater runoff has spread far to the east, the content of nutrients in it has noticeably decreased at a short distance from the mouth.

Return of the silicon inorganic form during mineralization provided the content of this element in the bottom waters within $30-40 \mu \mathrm{M}$ that is comparable with the silicic acid content in the river runoff (Fig. 5, h). The nitrates content in the bottom waters $(5-10 \mu \mathrm{M})$ did not attain $35 \mu \mathrm{M}$ in the Danube runoff, but exceeded the nitrates concentration in the surface waters by about 50-100 times (Fig. 5, l). No significant differences in the phosphate contents in the surface and bottom waters were revealed (Fig. $5, i, j$ ).

The nitrites distributions on the surface and bottom horizons were very similar to the distribution of nitrates, but their concentrations were lower. With distance from the mouth, the nitrite content in the surface waters (its maximum $1.7 \mu \mathrm{M}$ was 
near the St.George branch decreased rapidly up to zero approximately in the place where the nitrates isoline $1 \mu \mathrm{M}$ passed. In the bottom waters of the whole polygon, the nitrite content was higher than that on the surface - about $0.2-0.5 \mu \mathrm{M}$.

In the freshened waters of the lens, its center was at $45.5^{\circ} \mathrm{N}$ and $30.5^{\circ} \mathrm{E}$ (proceeding from the warm water layer thickness, the lens represented a small-scale anticyclonic gyre, but the data on the currents are absent), the oxygen and nutrients contents did not differ from those in the surrounding surface waters. However, the bottom waters, having been compared to the background values, contained more oxygen (70\%- saturation versus 30\%), less silicic acid (5 $\mu \mathrm{M}$ versus $30-50 \mu \mathrm{M}$ ), less nitrates $(1 \mu \mathrm{M}$ versus $5-7 \mu \mathrm{M}$ ), but more phosphates (more than $1 \mu \mathrm{M}$ versus $0.3-0.4 \mu \mathrm{M})$. One can assume that the processes of mineralization began in the lens bottom waters, but they did not attain intensity observed in the rest of the polygon.

In the surface waters of the Black Sea deep part, the photosynthesis limiting elements are the inorganic nitrogen compounds [31], whereas in the coastal regions phosphates [32] are considered to be a limiting element. At that at abundance of these elements, the Redfield optimum mole ratio between them should be 16:1. But in the situation observed in August, 2009, it seems difficult to determine unambiguously the limiting element as the mole ratio of the inorganic (nitrate) nitrogen $\left(\mathrm{N}_{\text {inorg }}\right)$ to the inorganic phosphorus $\left(\mathrm{P}_{\text {inorg }}\right)$ in the estuarine region (at a distance of 10 miles from the coast) decreased from approximately 30:1 to 1: 1 .

It is also difficult to assume what species of phytoplankton should predominantly develop. Abundance of silicic acid near the coast and the high $\mathrm{N}_{\text {inorg }} / \mathrm{P}_{\text {inorg }}$ ratio are favorable for growth of diatoms [33, 34]. At a distance of 10 miles from the coast, lack of silicon and low content of the nitrogen mineral forms should have resulted in development of the other phytoplankton species including coccolithophorides [35-37]. At that high concentrations of silicon were present in the bottom waters that, during upwelling, could again change the situation in favor of growth of diatoms and others.

\section{Along-coastal upwelling in the Danube mouth}

In 3 expeditions out of 7 ones performed by MHI in 1997-2013, the alongcoastal upwelling was observed in the region under study. The most contrast change in distribution of hydrological and hydrochemical characteristics, was revealed in September, 2013. The freshened surface waters near the coast with salinity $16.5-16.6 \%$ and temperature of $18-19{ }^{\circ} \mathrm{C}$ were replaced by the bottom waters from the shelf open part with salinity about $18 \%$ and temperature $9-10{ }^{\circ} \mathrm{C}$ (Fig. 6, $a-d$ ).

At a distance from the coast, two lenses of the freshened and worm waters were formed (the bottom water salinity was less than $17.5 \%$, temperature exceeded $15^{\circ} \mathrm{C}$ ) (Fig. 6, $b, d$ ): the first lens was opposite the Dniester mouth, the center coordinates of the other were $45.7^{\circ} \mathrm{N}, 30.6^{\circ} \mathrm{E}$. The diameter and the thickness of both of them were about 20 miles and $20 \mathrm{~m}$, respectively. The oxygen and silicic acid contents in the bottom waters of these lenses significantly differed from the background values. 
Note that in September, on this part of the shelf (permanently supplied with the nutrients of the freshwater runoff) the surface waters are expected to be oversaturated with oxygen. Actually, the surface waters saturation with oxygen on the southeastern part of the polygon (not affected by upwelling) was about 105\% (Fig. 6,e). However, elevation of the bottom waters, oxygen saturation of which did not exceed 50\%, to the surface (Fig. 6, $f$ ) led to the ecologically dangerous situation when the oxygen saturation of the whole water thickness at a distance of 2-3 miles to the southwest from the Danube mouth did not exceed $80 \%$. One can suppose that such upwellings could elevate even more oxygen-exhausted waters to the surface and, thus, provoke fish mortality regularly observed on NWS before.
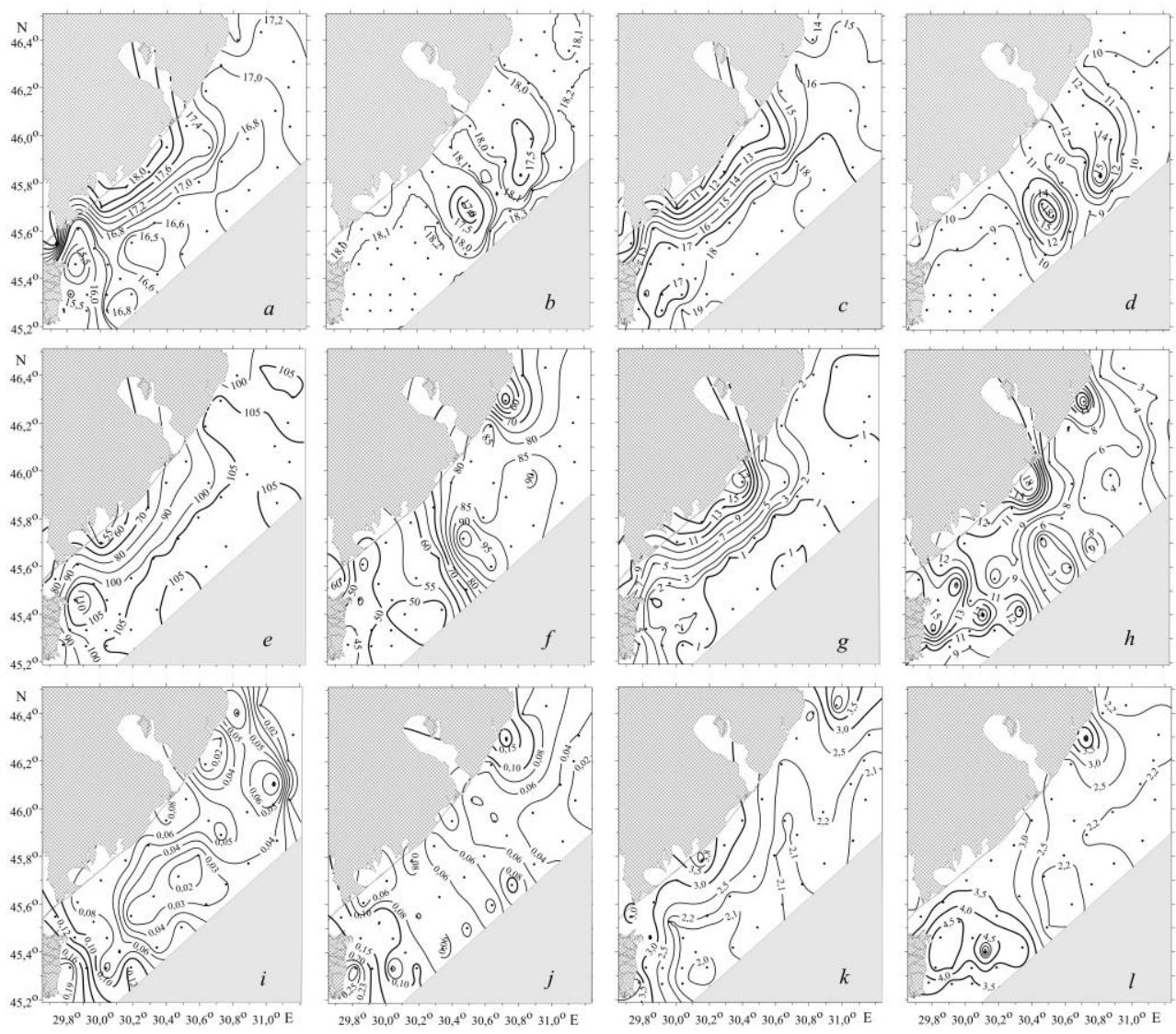

F i g. 6. Distribution of salinity, $\%(a, b)$, temperature, ${ }^{\circ} \mathrm{C}(c, d)$, oxygen saturation, $\%(e, f)$, content $(\mu \mathrm{M})$ of silicic acid $(g, h)$, phosphate $(i, j)$ and nitrate $(k, l)$ in the surface $(a, c, e, g, i, k)$ and bottom $(b, d, f, h, j, l)$ waters in September, 2013

The upwelling effect upon the nutrients distribution in the surface waters was the strongest upon silicic acid, the content of which was $1 \mu \mathrm{M}$ (proceeding from the concentrations remained in the southeast) and increased by more than an order near the coast (Fig. 6, $g, h$ ). This fact confirms the conclusions [18] on the additional source of silicic acid in the surface waters of the Danube estuary region.

Probably, due to the phosphates insignificant concentrations (lower than $0.1 \mu \mathrm{M})$ both in the surface and bottom waters, no significant upwelling-induced PHYSICAL OCEANOGRAPHY VOL. 26 ISS. 4 (2019) 
changes in their content were observed (Fig. 6,i,j). Also the nitrates content did not change much; though it should be noted that their concentrations in the bottom waters $(4-5 \mu \mathrm{M})$ were higher than in the surface ones $(2-3 \mu \mathrm{M})$ (Fig. $6, k, l)$. Thus, the process of POM mineralization in the bottom waters constitutes a source both of silicic acid and nitrates for the surface waters.

\section{Pressing of the transformed river flow to the Black Sea western coast}

The situation when the Danube flow, being influenced by the wind conditions, was blocked and transformed into a narrow along-coastal stream, was observed in October, 2010 when almost the whole water area under investigation was filled with the waters from the shelf open part, and the river flow narrowed along the Black Sea western coast (Fig. 7).
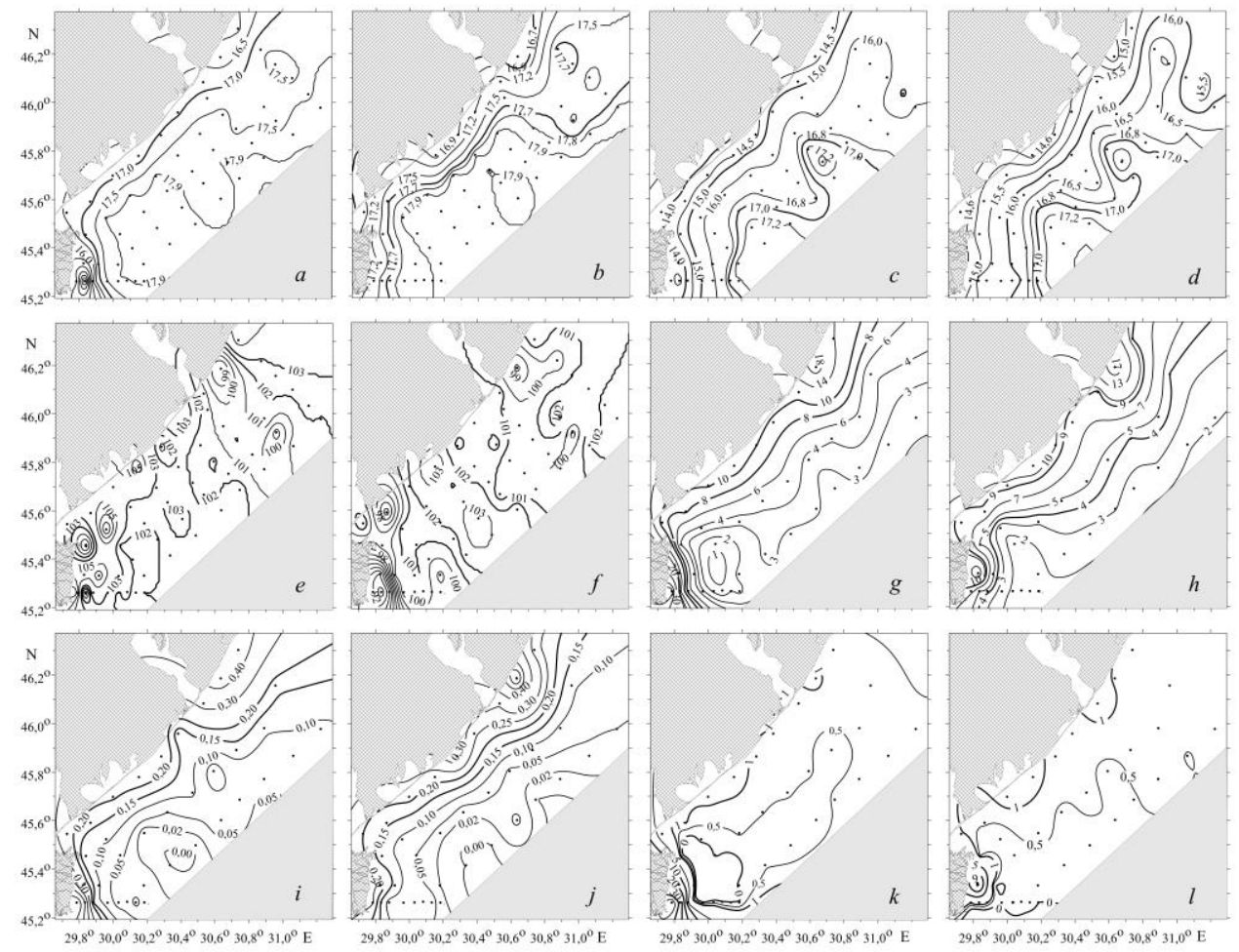

F i g. 7. Distribution of salinity, $\%(a, b)$, temperature, ${ }^{\circ} \mathrm{C}(c, d)$, oxygen saturation, $\%(e, f)$, content $(\mu \mathrm{M})$ of silicic acid $(g, h)$, phosphate $(i, j)$ and nitrate $(k, l)$ in the surface $(a, c, e, g, i, k)$ and bottom $(b, d, f, h, j, l)$ waters in October, 2010

Only in this stream (its width was not more than 10 miles), the surface water salinity was lower than $17.5 \%$, on the rest of the polygon - more than $17.9 \%$ (Fig. 7, a). It became the defining factor in distribution of the nutrients: near the estuary, the concentrations of silicic acid and phosphate exceeded 8 and $0.2 \mu \mathrm{M}$, respectively; whereas in the entire water column of the rest of the polygon, they were by an order lower (Fig. 7, $g, i$ ). Vertical distributions of all the hydrological and hydrochemical characteristics were almost monotonous; differences between 
the surface and bottom waters were observed only in the three-mile zone adjacent to the Sulina and St.George branches.

Note the following features in distribution of the hydrochemical elements while pressing of the transformed Danube flow to the western coast:

- ecologically safe, 100-102\% saturation of the whole water column;

- very low concentrations of all the nutrients in the waters of the shelf open part: silicic acid $-2-3 \mu \mathrm{M}$; nitrates - lower than $1 \mu \mathrm{M}$, phosphates $-0.1 \mu \mathrm{M}$; whereas near the St.George branch, the nutrients contents in the surface waters were almost by an order higher: silicic acid - $49 \mu \mathrm{M}$; nitrates - $49 \mu \mathrm{M}$; phosphates $-0.7 \mu \mathrm{M}$.

The shelf water temperature and the solar illumination at the beginning of October would have been quite enough to provide an outbreak of phytoplankton bloom if the river runoff spread to the east or northeast. However, low content of nutrients was not enough to saturate the surface waters with oxygen by more than 102-103\%. Thus, in October 2010, the NWS waters did not differ from those of the deep part of the Black Sea (except for the three-mile zone near the mouth). In other words, ventilation of the NWS waters in the autumn period was revealed.

In all the discussed cases (spread of the transformed river flow to the east, its blocking along the coast and upwelling), difference in oxygen saturation of the surface and bottom waters produced the strongest effect upon the silicic acid content. In the cases of the bottom waters hypoxia, the silicic acid content there was at least by an order higher than in the surface waters. This confirms the conclusions derived in [18] that on NWS during a warm season, an additional source of inorganic silicon occurs due to mineralization of its organic forms brought by the freshwater runoff, and precipitating as the river waters transform.

\section{Conclusion}

The concentrations of nutrients in the open part of the NWS, waters which, in autumn, 2010 pressed the transformed freshwater runoff to the western coast, were very low. Specially note low content of silicic acid. It indicates the fact that the hazardous process of change in the phytoplankton species composition still continues, hence, altering the entire trophic chain in the Black Sea.

In the NWS surface waters, the process of active photosynthesis in summer is accompanied by almost complete extraction of silicic acid and nitrates; at that the nitrates are consumed even in early winter.

The processes of the along-coastal upwelling in summer can result in decrease of the oxygen content in the surface waters of the Danube mouth and, consequently, fish mortality on the northwestern shelf.

The processes of the particulate organic matter mineralization on NWS constitute an additional source of: silicic acid - in a warm period, and nitrates even in early winter. The silicic acid content in the bottom waters can be even higher than that in the river runoff.

The distributions of phosphates and nitrites in the NWS surface and bottom waters differ insignificantly. As for phosphates, it can be related to their rapid turnover in the processes of photosynthesis and POM mineralization. Concerning nitrites, perhaps, it can be explained by the fact that they are an intermediate product in the nitrification and de-nitrification processes. 


\section{REFERENCES}

1. Berlinsky, N.A., Garkavaya, G.P. and Bogatova, J.I., 2003. Anthropogenic Euthrophication Problems and Hypoxia Development in the Northwestern Part of the Black Sea. Ecology of the Sea = Ekologiya Morya, 63, pp. 17-22 (in Russian).

2. Kubryakov, A.A., Stanichny, S.V. and Zatsepin A.G., 2018. Interannual Variability of Danube Waters Propagation in Summer Period of 1992-2015 and Its Influence on the Black Sea Ecosystem. Journal of Marine Systems, [e-journal] 179, pp.10-30. https://doi.org/10.1016/j.jmarsys.2017.11.001

3. Finenko, Z.Z., Suslin, V.V. and Kovaleva, I.V., 2014. Seasonal and Long-Term Dynamics of the Chlorophyll Concentration in the Black Sea According to Satellite Observations. Oceanology, [e-journal] 54(5), pp. 596-605. https://doi.org/10.1134/S0001437014050063

4. Kubryakova, E.A., Kubryakov, A.A. and Stanichny, S.V., 2018. Impact of Winter Cooling on Water Vertical Entrainment and Intensity of Phytoplankton Bloom in the Black Sea. Physical Oceanography, [e-journal] 25(3), pp. 191-206. doi:10.22449/1573-160X-2018-3-191-206

5. Il'in, Yu.P., 2006. Gidrologicheskiy Rezhim Rasprostraneniya Rechnykh Vod v SeveroZapadnoy Chasti Chernogo Morya. In: UHMI, 2006. Nauchnye Trudy UkrNIGMI [Scientific Works of UHMI]. Kiev, UHMI. Iss. 255, pp. 242-251. Available at: uhmi.org.ua>pub/np/255/4_Ilyin.pdf [Accessed: 04.10.2018] (in Russian).

6. Ukrainskii, V.V. and Popov, Yu.I., 2009. Climatic and Hydrophysical Conditions of the Development of Hypoxia in Waters of the Northwest Shelf of the Black Sea. Physical Oceanography, [e-journal] 19(3), pp. 140-150. https://doi.org/10.1007/s11110-009-9046-6

7. Tolmazin, D., 1985. Changing Coastal Oceanography of the Black Sea. I: Northwestern Shelf. Progress in Oceanography, [e-journal] 15(4), pp. 217-276. https://doi.org/10.1016/00796611(85)90038-2

8. Zaitsev, Yu.P., 1992. [State of the Shelf Zone Ecology in the Black Sea nearby the Ukrainian Coast (review)]. Hydrobiological Journal, 28(4), pp. 318 (in Russian).

9. Aubrey, D., Moncheva, S., Demirov, E., Diaconu, V. and Dimitrov, A., 1996. Environmental Changes in the Western Black Sea Related to Anthropogenic and Natural Conditions. Journal of Marine Systems, [e-journal] 7(2-4), pp. 411-425. https://doi.org/10.1016/09247963(95)00031-3

10. Humborg, C., v. Bodungen, B., Ittekkot, V. and Cociasu, A., 1997. Effect of Danube River Dam on Black Sea Biogeochemistry and Ecosystem Structure. Nature, [e-journal] 386, pp. 385-388. https://doi.org/10.1038/386385a0

11. Zaitsev, Yu. and Mamaev, V., 1997. Marine Biological Diversity in the Black Sea: a Study of Change and Decline. New York: United Nations Publications, 208 p.

12. Garkavaja, G.P., Bogatova, Ju.I. and Berlinskij, N.A., 2000. [Formation of Hydrochemical Conditions in the Coastal Waters of the Danube Mouth]. In: MHI, 2000. Ecological Safety of Coastal and Shelf Zones and Comprehensive Use of Shelf Resources. Sevastopol: ECOSI- Gidrofizika, pp. 133-141 (in Russian).

13. Friedrich, J., Dinkela, C., Friedl, G., Pimenov, N., Wijsman, J., Gomoiu, M.-T., Cociasu, A., Popae, L. and Wehrli, B., 2002. Benthic Nutrient Cycling and Diagenetic Pathways in the North-Western Black Sea. Estuarine, Coastal and Shelf Science, [e-journal] 54(3), pp. 369383. https://doi.org/10.1006/ecss.2000.0653

14. Zaitsev, Yu.P. and Polikarpov, G.G., 2002. Ecological Processes in Critical Zones of the Black Sea (Results Synthesis of Two Research Directions, Middle of the XXth - Beginning of the XXIth Centuries). Marine Ekological Journal = Morskoj Ehkologicheskij Zhurnal. 1(1), pp. 33-55 (in Russian).

15. Ragueneau, O., Lancelot, C., Egorov, V., Vervlimmeren, J., Cociasu, A., Déliat, G., Krastev, A., Daoud, N., Rousseau, V., 2002. Biogeochemical Transformations of Inorganic Nutrients in the Mixing Zone between the Danube River and the North-Western Black Sea. Estuarine, Coastal and Shelf Science, [e-journal] 54(3), pp. 321-336. https://doi.org/10.1006/ecss.2000.0650 
16. Grégoire, M. and Lacroix, G., 2003. Exchange Processes and Nitrogen Cycling on the Shelf and Continental Slope of the Black Sea Basin. Global Biogeochemical Cycles, [e-journal] 17(2), 1073. doi:10.1029/2002GB001882

17. Berlinsky, N.A., Kosarev, A.N., Bogatova, Yu.I. and Garkavaya, G.P., 2004. Influence of Danube on the Environmental Conditions in the North-Western Part of the Black Sea. Vestnik Moskovskogo Universiteta. Seria 5, Geografia, [e-journal] (5), pp. 17-21.

18. Zaytsev, Yu.P., Aleksandrov, B.G. and Minicheva, G.G., eds., 2006. [The Northwestern Part of the Black Sea: Biology and Ecology]. Kiev: Naukova Dumka, 701 p. (in Russian).

19. Shapiro, G.I., Wobus, F. and Aleynik, D.L., 2011. Seasonal and Inter-Annual Temperature Variability in the Bottom Waters over the Western Black Sea Shelf. Ocean Science, [ejournal] 7(5), pp. 585-596. https://doi.org/10.5194/os-7-585-2011

20. Kondratyev, S.I., 2014. Features of Oxigen Spatial Distribution in the Coastal Waters of the Danube Region in 1997-2010. Morskoy Gidrofizicheskiy Zhurnal, (3), pp. 60-76 (in Russian).

21. Kondratev, S.I., 2015. Peculiarities of Nutrients Distribution in the Coastal Waters near the Danube Estuary in 1997-2013. Physical Oceanography, [e-journal] (5), pp. 32-48. doi:10.22449/1573-160X-2015-5-32-48

22. Oguz, T. and Velikova, V., 2010. Abrupt Transition of the Northwestern Black Sea Shelf Ecosystem from a Eutrophic to an Alternative Pristine State. Marine Ecology Progress Series, [e-journal] 405, pp. 231-242. doi:10.3354/meps08538

23. Bologa, A.S. and Sava, D., 2012. Present State and Evolution Trends of Biodiversity in the Black Sea: Decline and Restoration. Journal of the Black Sea/Mediterranean Environment, 18(2), pp. 144-154. Available at: http://blackmeditjournal.org/wp-content/uploads/ vol18no2pdf5.pdf [Accessed: 04.10.2018].

24. Capet, A., Beckers, J.-M. and Grégoire, M., 2013. Drivers, Mechanisms and Long-Term Variability of Seasonal Hypoxia on the Black Sea Northwestern Shelf - is there Any Recovery after Eutrophication? Biogeosciences, [e-journal] 10(6), pp. 3943-3962. doi:10.5194/bg-10-3943-2013

25. Loeva, I.D., Ukrainskii, V.V, Orlova, I.G. and Kovalishina, S.P., 2013. Modern Ecological State of the North-Western Part of the Black Sea. In: MHI, 2013. Ecological Safety of Coastal and Shelf Zones and Comprehensive Use of Shelf Resources. Sevastopol: ECOSI-Gidrofizika. Iss. 27, pp. 237-242 (in Russian).

26. Berlinsky, N.A., Den'ga, Yu.M., Matveev, A.V., Podust, O.S., Popov, Yu.I. and Tretyak, I.P., 2014. The Influence of Marine Environment Variability to the Dynamic of the Black Sea Phillophora Area (Zernov Field). Odesa National University Herald. Geography and Geology, 19(2), pp. 40-57 (in Russian).

27. Tkachenko, F.P. and Tretiak I.P., 2015. Macrophytobenthos of Botanical Reserve National Significance of "Zernov Phyllophora Field" (Ukraine). Algologia, 25(3), pp. 238-246. http://dx.doi.org/10.15407/alg25.03.238 (in Russian).

28. The Association of Ukrainian Fishermen Considers a Man to Be Guilty of Each fish Mortality. online Available at: https://mk.mk.ua/rubric/crime/2018/08/27/57927/ [Accessed: 04.10.2018] (in Russian).

29. Bordovskiy, O.K. and Chernyakova, A.M., 1992. Modern Methods of Ocean Hidrochemical Investigations. Moscow, 1992. 201 p. (in Russian).

30. Bol'shakov, V.S., 1970. [Transformation of River Waters in the Black Sea]. Kiev: Naukova Dumka, 328 p. (in Russian).

31. Krivenko, O.V., 2008. Contents and Uptake of Inorganic Nitrogen in the Black Sea. Marine Ekological Journal = Morskoj Ehkologicheskij Zhurnal, 7(4), pp. 13-26 (in Russian).

32. Mikaelyan, A.S., Zatsepin, A.G. and Chasovnikov, V.K., 2013. Long-Term Changes in Nutrient Supply of Phytoplankton Growth in the Black Sea. Journal of Marine Systems, [ejournal] 117-118, pp. 53-64. https://doi.org/10.1016/j.jmarsys.2013.02.012 
33. Egge, J.K. and Aksnes, D.L., 1992. Silicate as Regulating Nutrient in Phytoplankton Competition. Marine Ecology Progress Series, 83, pp. 281-289. https://doi.org/10.3354/meps083281

34. Stelmakh, L.V. and Mansurova, I.M., 2012. Ecological and Physiological Basis of Phytoplankton Biodiversity in the Black Sea. Optimization and Protection of Ecosystems. Simferopol: TNU. Iss. 7, pp. 149-158 (in Russian).

35. Cokacar, T., Oguz, T. and Kubilay, N., 2004. Satellite-Detected Early Summer Coccolithophore Blooms and Their Interannual Variability in the Black Sea. Deep Sea Research Part I: Oceanographic Research Papers, [e-journal] 51(8), pp. 1017-1031. https://doi.org/10.1016/j.dsr.2004.03.007

36. Mikaelyan, A.S., Silkin, V.A. and Pautova, L.A., 2011. Coccolithophorids in the Black Sea: Their Interannual and Long-Term Changes. Oceanology, [e-journal] 51(1), pp. 39-48. https://doi.org/10.1134/S0001437011010127

37. Mikaelyan, A.S., Pautova, L.A. and Chasovnikov, V.K., 2015. Alternation of Diatoms and Coccolithophores in the Northeastern Black Sea: a Response to Nutrient Changes. Hydrobiologia, 755(1), pp. 89-105. doi:10.1007/s10750-015-2219-z

About the author:

Sergey I. Kondratev - Senior Research Associate, Marine Hydrophysical Institute of RAS (2 Kapitanskaya Str., Sevastopol, 229011, Russian Federation), Ph.D. (Chem. Sci.), ORCID ID: 0000-0002-2049-7750, skondratt@mail.ru

The author has read and approved the final manuscript.

The author declares that he has no conflict of interest. 